\title{
Even Finance Professors Lean Left
}

\section{Emre Kuvvet}

As in most academic fields, the top academic finance departments and journals guide the direction of scholarly research. Preferences, tastes, and sensibilities of the faculty at the top finance departments and the editorial boards at top finance journals can have a considerable effect on the acceptable research questions in those journals. It is well known that a person's political ideology shapes his outlook on scientific issues. ${ }^{1}$ Yet little is known about the political ideologies of finance professors at these elite institutions and journals. This analysis of the political party affiliations of faculty at the top twenty finance departments and of the editorial boards at the top three finance journals shows that both institutions lean considerably to the left. Results also suggest that finance departments will become even less politically diverse in the future.

\section{Top Finance Department Rankings}

The top twenty finance departments at American universities and colleges are identified using Arizona State University's (ASU) Finance Rankings, a website that ranks finance departments by the number of articles published by faculty in the top three finance journals. This study looks at the last twenty years of data, from 2000 to 2019, and includes only U.S. institutions outside of the states of Michigan, Missouri, and Washington, states that don't record the party affiliations of their registered voters.

The University of Illinois-Urbana/Champaign and Yale University are included in this sample, even though they are ranked in $22^{\text {nd }}$ and $25^{\text {th }}$, respectively, to make twenty the total number of institutions in the sample.

1 "Americans, Politics and Science Issues," Pew Research, July 1, 2015.

Emre Kuvvet is an Associate Professor of Finance in the Department of Finance at Nova Southeastern University in Fort Lauderdale. Prof. Kuvvet's research includes issues in law and finance, corporate misconduct, and political economy of finance. He has published widely and his work has been profiled in the Chicago Tribune, the New York Times, and CFA Digest. 


\section{Party Affiliation Data}

All full-time tenured or tenure-track faculty are identified from CVs posted on the department websites of their respective institutions. This study excludes visiting faculty, emeritus, adjunct faculty, clinical faculty, lecturers, professors of practice, joint appointments, department affiliates, and secondary faculty.

Party affiliations of the faculty at the top twenty finance departments are culled from various sources. For states such as Illinois and Massachusetts, party affiliations of faculty were acquired under Freedom of Information Act requests. Illinois does not require voters to state a party affiliation when registering. However, whether the individual requested a Republican or Democrat ballot for the most recent primary election is public record. For institutions in Illinois party affiliation is assigned based on the party of the primary ballot requested, Democrat or Republican. Faculty who are registered to vote but did not vote in a recent primary are classified as No Party Affiliation. Illinois faculty not registered to vote in that state are classified as Not Registered.

Voter records of New York and New Jersey were retrieved from Stephen P. Morse's “One-Step Search Tool” generator. Voter records for Pennsylvania and California faculty were purchased from those states' Department of State. Voter records for the states of North Carolina, Ohio, Connecticut, Florida, and the District of Columbia were obtained from the website VoterRecords.com. In addition, voter records for Austin, Texas, are from the Travis County Tax Office. As in Illinois, Texas does not show the party affiliation of registered voters, but the party of primary ballots requested is public information and thereby assigned. Maryland faculty registration data was purchased from the Maryland State Board of Elections. Statewide voter records for Georgia were obtained from the Georgia Secretary of State. The sample derived from these efforts consists of 497 full-time tenured or tenure-track faculty at the top twenty finance departments in the U.S. located in states that record political party affiliation of registered voters.

\section{Political Affiliations of Top Twenty Finance Departments}

As Table 1 indicates, New York University is ranked number one among finance departments in the U.S., with Harvard University coming in at number two. Both institutions have a political affiliation ratio among faculty of 10 Democrats to 1 Republican. (At NYU, eight faculty have no party affiliation and thirteen are not registered to vote.) In other words, for the top two 
ranked finance departments in the country, for every Republican there are 10 Democrats among the faculty.

University of Chicago, ranked number three, is often regarded as one of the few conservative institutions of higher learning in the U.S. This is likely due to the prominence of its free-market oriented "Chicago School of Economics" and its renowned Committee on Social Thought, which has boasted such ostensibly conservative luminaries as philosopher Allan Bloom, novelist Saul Bellow, and sociologist Edward Shils. More recently, in 2014, President Robert J. Zimmer and then-Provost Eric Isaacs appointed a committee of university faculty to articulate the "Chicago Principles," a vigorous defense of free speech on campus. However, empirical data for this proposition has been lacking. As mentioned, Illinois does not record voter registration data by political party and previous studies examining the political affiliations of faculty have had to exclude the UoC from their samples. However, the data obtained through the primary ballot party identification method and a FOIA request for the finance unit at the UoC belies the assumption of that institution's political conservatism. The finance faculty at the UoC has a Democrat to Republican political affiliation ratio of 9 to 1.

The University of Pennsylvania, at number four on the ranking list, has 8 Democrats and 5 Republicans in the finance department, for a Democrat to Republican ratio of 1.6 to 1 . Among the top four finance departments, the University of Pennsylvania seems to be the most politically diverse department.

The Massachusetts Institute of Technology (MIT) is ranked number five among finance departments and does not have any Republicans in its finance group. Its Democrat to Republican ratio is 3 to 0 . Duke University is ranked number six and has a Democrat to Republican ratio of 5 to 1.

Columbia University's finance division is ranked number seven in the country and has 7 Democrats and 2 Republicans. One faculty member is registered with the Working Families Party, which is a left-wing progressive party, and therefore is counted as a Democrat, making the Democrat to Republican ratio there 3.5 to 1 .

Stanford University is number eight in the rankings with a heavily left-leaning finance faculty. There are no Republicans, so the Democrat to Republican ratio is 6 to O. UCLA is ranked number nine, with 1 Democrat, 1 Republican, and 2 Libertarian finance faculty. Among these top twenty institutions, UCLA's finance faculty are the most politically diverse. 
Ohio State University-Columbus ranks number ten and has 6 Democrats and 2 Republicans in the finance department. The Democrat to Republican ratio is 3 to 1 . Northwestern University comes next at number eleven and is the most left-leaning department on my list: with no Republicans the Democrat to Republican ratio is 10 to 0 .

The University of North Carolina-Chapel Hill at number twelve has 5 Democrats and 2 Republicans. The Democrat to Republican ratio is 2.5 to 1 . The University of Texas-Austin at number thirteen has 7 Democrats and 2 Republicans for a Democrat to Republican ratio of 3.5 to 1.

The University of California-Berkley is ranked number fourteen. Its finance group leans left, with a Democrat to Republican ratio of 5 to 1 . Cornell University, ranked fifteenth, has a heavily left-leaning department, with 7 Democrats and only 1 Republican. Number sixteen Boston College, with 7 Democrats and 2 Republicans, has a Democrat to Republican ratio of 3.5 to 1.

The University of Southern California is number seventeen and its finance department is very left-leaning. The Democrat to Republican ratio is 7 to 1 . Number eighteen, the University of Maryland-College Park, has 4 Democrats and 3 Republicans. The Democrat to Republican ratio is 1.33 to 1 . The University of Illinois-Urbana/Champaign, ranked number nineteen, has 8 Democrats and 3 Republicans. The Democrat to Republican ratio is 2.67 to 1.

Finally, ranked at number twenty, Yale University is the second most liberal department after Northwestern University. It has no Republicans and 9 Democrats. The Democrat to Republican ratio is 9 to 0.

In total, there are 134 Democrats, 29 Republicans, and 2 Libertarian faculty members at the top twenty finance departments, with the Democrat to Republican ratio at 4.62 to 1 . In other words, for every Republican, there are almost 5 Democrats in those elite departments. Four of the top twenty departments have no Republicans. Nineteen of the top twenty departments have a large Democrat majority. 
Table 1. Political Affiliations of Top Twenty Finance Departments

\begin{tabular}{|c|c|c|c|c|c|c|c|}
\hline Rank & Institution & $\begin{array}{l}\text { Democrat } \\
\text { to Repub- } \\
\text { lican Ratio }\end{array}$ & $\begin{array}{l}\text { Dem- } \\
\text { ocrat }\end{array}$ & $\begin{array}{l}\text { Repub- } \\
\text { lican }\end{array}$ & $\begin{array}{l}\text { No Pary } \\
\text { Affilia- } \\
\text { tion }\end{array}$ & $\begin{array}{l}\text { Not } \\
\text { Regis- } \\
\text { tered }\end{array}$ & $\begin{array}{l}\text { Liber- } \\
\text { tarian }\end{array}$ \\
\hline 1 & New York University & 10.00:1 & 10 & 1 & 8 & 13 & 0 \\
\hline 2 & Harvard University & 10.00:1 & 10 & 1 & 11 & 6 & 0 \\
\hline 3 & University of Chicago & $9.00: 1$ & 9 & 1 & 5 & 15 & 0 \\
\hline 4 & $\begin{array}{l}\text { University of Pennsyl- } \\
\text { vania }\end{array}$ & $1.60: 1$ & 8 & 5 & 12 & 16 & 0 \\
\hline 5 & $\begin{array}{l}\text { Massachussetts Institute } \\
\text { of Technology }\end{array}$ & $3.00: 0$ & 3 & 0 & 8 & 9 & 0 \\
\hline 6 & Duke University & $5.00: 1$ & 5 & 1 & 7 & 5 & 0 \\
\hline 7 & Columbia University & $3.50: 1$ & 7 & 2 & 6 & 12 & 0 \\
\hline 8 & Stanford University & $6.00: 0$ & 6 & 0 & 5 & 9 & 0 \\
\hline 9 & UCLA & $1.00: 1$ & 1 & 1 & 5 & 6 & 2 \\
\hline 10 & $\begin{array}{l}\text { Ohio State Universi- } \\
\text { ty-Columbus }\end{array}$ & $3.00: 1$ & 6 & 2 & 3 & 8 & 0 \\
\hline 13 & Northwestern University & 10.00:0 & 10 & 0 & 9 & 11 & 0 \\
\hline 14 & $\begin{array}{l}\text { University of North } \\
\text { Carolina-Chapel Hill }\end{array}$ & $2.50: 1$ & 5 & 2 & 10 & 7 & 0 \\
\hline 15 & $\begin{array}{l}\text { University of Texas-Aus- } \\
\text { tin }\end{array}$ & $3.50: 1$ & 7 & 2 & 9 & 7 & 0 \\
\hline 16 & $\begin{array}{l}\text { University of Califor- } \\
\text { nia-Berkeley }\end{array}$ & $5.00: 1$ & 5 & 1 & 1 & 12 & 0 \\
\hline 17 & Cornell University & $7.00: 1$ & 7 & 1 & 9 & 7 & 0 \\
\hline 18 & Boston College & $3.50: 1$ & 7 & 2 & 9 & 9 & 0 \\
\hline 18 & $\begin{array}{l}\text { University of Southern } \\
\text { Califonia }\end{array}$ & $7.00: 1$ & 7 & 1 & 7 & 21 & 0 \\
\hline 20 & $\begin{array}{l}\text { University of Mary- } \\
\text { land-College Park }\end{array}$ & $1.33: 1$ & 4 & 3 & 5 & 5 & 0 \\
\hline 22 & $\begin{array}{l}\text { University of Illinois-Ur- } \\
\text { bana/Champaign }\end{array}$ & $2.67: 1$ & 8 & 3 & 4 & 12 & 0 \\
\hline \multirow[t]{3}{*}{25} & Yale University & $9.00: 0$ & 9 & 0 & 6 & 3 & 0 \\
\hline & Ratio & $4.62: 1$ & & & & & \\
\hline & Total & 134.29 & 134 & 29 & 139 & 193 & 2 \\
\hline
\end{tabular}

\section{Future of Political Diversity in Academic Finance Departments}

Currently, there is little political diversity in the twenty most elite finance departments. Will those departments become more politically diverse or more left-leaning in the future? To answer these questions the political affiliations of faculty at the top twenty finance departments is analyzed by age. Column (1) 
of Table 2 shows the age range of the faculty for the top twenty finance departments. The Democrat to Republican ratio for the age group thirty-five and younger is 18 to 0 . The upcoming generation of faculty at the top twenty finance departments is even more heavily left-leaning than the older age groups. For faculty over fifty-five years of age but younger than sixty-six, the Democrat to Republican ratio is 4.33 to 1 .

Table 2. Political Affiliations of Faculty at Top

\section{Twenty Finance Departments by Age}

\begin{tabular}{|c|c|c|c|c|c|c|}
\hline Faculty Age & $\begin{array}{l}\text { Democrat } \\
\text { to Republi- } \\
\text { can Ratio }\end{array}$ & Democrat & Republican & $\begin{array}{l}\text { No Party } \\
\text { Affiliation }\end{array}$ & $\begin{array}{c}\text { Not Regis- } \\
\text { tered }\end{array}$ & $\begin{array}{l}\text { Libertar- } \\
\quad \text { ian }\end{array}$ \\
\hline Age $=<35$ & $18.00: 0$ & 18 & 0 & 21 & 80 & 1 \\
\hline $35<$ Age $=<45$ & $6.50: 1$ & 26 & 4 & 33 & 58 & 0 \\
\hline $45<$ Age $=<55$ & $3.33: 1$ & 20 & 6 & 41 & 35 & 0 \\
\hline $55<$ Age $=<65$ & $4.33: 1$ & 39 & 9 & 27 & 11 & 1 \\
\hline $65<$ Age & $3.10: 1$ & 31 & 10 & 17 & 9 & 0 \\
\hline
\end{tabular}

In Table 3, political affiliations of the faculty members at the top twenty finance departments based on academic rank are analyzed instead of age. The Democrat to Republican ratio for the assistant professors is 10.5 to 1 , while the ratio for full professors is 4.04 to 1 . Thus, confirming the age group analysis, the academic rankings analysis suggests the future composition of the faculty at the top twenty finance departments will likely be even more left-leaning than the current faculty.

Table 3: Political Affiliations of Faculty in Top Finance Departments by Academic Rank

\begin{tabular}{|c|c|c|c|c|c|c|}
\hline $\begin{array}{c}\text { Academic } \\
\text { Rank }\end{array}$ & $\begin{array}{l}\text { Democrat } \\
\text { to Republi- } \\
\text { can Ratio }\end{array}$ & Democrat & Republican & $\begin{array}{l}\text { No Party } \\
\text { Affiliation }\end{array}$ & $\begin{array}{c}\text { Not Regis- } \\
\text { tered }\end{array}$ & $\begin{array}{l}\text { Libertar- } \\
\quad \text { ian }\end{array}$ \\
\hline $\begin{array}{l}\text { Assistant } \\
\text { Professor }\end{array}$ & $10.50: 1$ & 21 & 2 & 29 & 91 & 0 \\
\hline $\begin{array}{l}\text { Associate } \\
\text { Professor }\end{array}$ & $5.33: 1$ & 16 & 3 & 24 & 38 & 1 \\
\hline Professor & $4.04: 1$ & 97 & 24 & 86 & 64 & 1 \\
\hline
\end{tabular}


Political Affiliations of the Editorial Boards of the Top Three Finance Journals

The Journal of Finance, the Journal of Financial Economics, and the Review of Financial Studies are widely considered to be the top three journals in finance. These journals not only determine the promotions and career outcomes of finance professors at those elite departments but also sway the direction of research in finance academia. Preferences and tastes of editorial boards can have considerable effect on the acceptable research questions at those journals.

Journal of Finance (JF) is the top journal. JF has thirty-eight individuals serving as editors and associate editors on its editorial board. Thirty of these individuals, or approximately 79 percent, are the faculty at U.S. institutions that are ranked in the top twenty list. Of the remainder, 13.2 percent come from foreign institutions, and only 7.9 percent come from the U.S. institutions that are not ranked in the top twenty. There are 8 Democrats and 0 Republicans on $J F$ 's editorial board. Seven members have no party affiliation and 10 members are not registered to vote. The rest of the board (14) come from foreign countries or states such as Michigan and Washington that do not keep records of the party affiliations of registered voters. The Democrat to Republican ratio for the editorial board at $J F$ is 8 to 0 .

The Journal of Financial Economics (JFE) has thirty-nine people serving as editors, associate editors, and advisory editors on its editorial board. Of these, 69.2 percent come from the top twenty institutions, 2.6 percent come from the foreign institutions, and 28.2 percent come from the U.S. institutions that are not in the top twenty. The Democrat to Republican ratio for the editorial board at JFE is 6.5 to 1.

Finally, the Review of Financial Studies (RFS) has thirty individuals serving as editors and associate editors on its editorial board. Of these, 73.3 percent come from the top twenty institutions, 16.7 percent come from foreign institutions, and only 10 percent come from the U.S. institutions that are not on the top twenty list. The Democrat to Republican ratio is 3 to 1.

The faculty at the top twenty finance departments and the editorial boards at the top three finance journals are intertwined. The majority of the editorial board members come from those departments. Naturally, the political ideologies of the faculty at the top twenty finance departments reflect the political affiliations of the editorial boards at the top three finance journals. However, the data suggest that the editorial boards seem to be even more left-leaning than the faculty at these departments. 
Table 4. Political Affiliations of Editorial Boards of Top Three Finance Journals

\begin{tabular}{|c|c|c|c|c|c|c|}
\hline $\begin{array}{l}\text { Journal } \\
\text { Name }\end{array}$ & $\begin{array}{l}\text { Democrat } \\
\text { to Republi- } \\
\text { can Ratio }\end{array}$ & Democrat & Republican & $\begin{array}{l}\text { No Party } \\
\text { Affiliation }\end{array}$ & $\begin{array}{c}\text { Not Regis- } \\
\text { tered }\end{array}$ & $\begin{array}{l}\text { Libertar- } \\
\quad \text { ian }\end{array}$ \\
\hline $\begin{array}{l}\text { Journal of } \\
\text { Finance }\end{array}$ & 8.0:0 & 8 & 0 & 7 & 13 & 0 \\
\hline $\begin{array}{l}\text { Journal of } \\
\text { Financial } \\
\text { Economics }\end{array}$ & $6.5: 1$ & 13 & 2 & 11 & 8 & 0 \\
\hline $\begin{array}{l}\text { Review of } \\
\text { Financial } \\
\text { Studies }\end{array}$ & 3.0:1 & 3 & 1 & 8 & 10 & 0 \\
\hline
\end{tabular}

\section{Conclusion}

The faculty at the top twenty finance departments and the editorial boards at the top finance journals are heavily left-leaning. There is little political diversity in the upper echelon of finance academia. This should be a concern for everybody in finance academia, as the faculty at those top departments not only produce most of the research in these top journals, but as members of the editorial boards of the top three finance journals, they also decide what type of research gets published in these journals.

But what is the solution for the groupthink problem in financial research? Trying to make these departments more politically diverse through hiring is a futile exercise. The younger faculty members at these departments who will replace the older faculty are even more heavily left-leaning. One option that might warrant consideration would be some kind of requirement to disclose or otherwise indicate the political ideology or partisan loyalties of authors who publish in financial research. The best method for such disclosure-one that would protect academic freedom and the integrity of research-should be the subject of further investigation.

Financial research, by its nature, is political. Scholarly papers in finance have public policy implications. Findings of research papers can be used to initiate new government policies or justify existing regulations. Political disclosure in research papers will allow readers to be more conscious of the authors' sensibilities. By being upfront with readers about their political ideology, the authors of papers will be able to establish a level of trust. One may argue that political disclosure in research papers will discredit scholarly papers. That 
seems unlikely. There already exist other types of disclosures in research papers. For instance, the Journal of Finance, the Journal of Financial Economics, and the Review of Financial Studies all require authors to disclose any financial interests related to their research. Authors' disclosing financial interests at the top three journals have not discredited their research thus far.

Political ideology can often supersede financial interest of an individual if political ideology and financial self-interest happen to clash. That some of the wealthiest individuals support higher taxes is well documented, as is the movement among investors away from profit maximization to "environmental, social, and governance issues." ${ }^{2}$ For the sake of transparency to the readers in financial research, it might be more important to disclose political ideology than one's financial interest. The Journal of Finance, the Journal of Financial Economics, and the Review of Financial Studies should extend their disclosure policies for authors and include “Disclosure of Political Ideology” for research articles.

2 C.K., "Why people vote against their economic interests," The Economist, June 5, 2018; Kim Iskyan, "When Woke St. and Wall St. Intersect," American Consequences, February 19, 2021. 